\title{
Psychological Symptoms in Young Adult Migraineurs
}

\author{
Turgay Akalin \\ Assistant Professor, Md, Neurologist, \\ Cyprus American University, Şht. Salahi Șevket Sk, Lefkoșa 99oı, Cyprus \\ Aysin Sinal \\ Associate Professor, Clinical Psychologist, \\ Girne American University, Üniversite Yolu Sk, Karaman 99320, Cyprus
}

Doi: 10.36941/mjss-2020-00o5

\section{Abstract}

We aimed to reveal psychological symptoms of young university students (18-25 y/o) with no secondary disease with complaints of migraine headaches. We compared the psychological symptoms with a young control group that did not present headaches and other studies examining migraines in different age groups to determine any similarities. The study consisted of 75 migraine cases; 13 with aura and 62 without aura) and 42 non-headache control subjects. The International Classification of Headache Disorders 3 (ICHD-3) with criteria questions and the Psychological Symptom Research Scale were applied to all participants and SPSS Statistics Program evaluated the data. Findings: 1) In the test of Descriptive Statistics for the Sample of Students, average values of both sexes were taken and found the average values of the migraine groups were higher than control group. 2) The Anova Test found differences in the diagnostic group besides depression (Somatisation $p<$., others $p<.01)$ with no significant difference in depression $(p=0.315)$. 3) The Pearson Correlation Analysis, found no association between age and psychological symptoms. There's a significant relationship between psychological symptoms with somatisation (besides paranoid) ( $p<.05$ ). There's a significant relationship between depression and other psychological symptoms ( $p<.05)$. There's a significant relationship between anxiety, obsession, interpersonal relationships, psychoticism, paranoia, anger, phobia, additional scale and other psychological symptoms $(p<.01)$. Result: The study demonstrated psychological symptoms in young migraineurs. The average psychological symptoms of both migraine groups were higher than the control group, this showed psychological symptom similarities between young migraineurs and migraine patients of different age groups.

Keywords: Headaches, Migraine, Migraine without Aura, Migraine with Aura, psychological symptom screening test SLC-9o-R, ICHD-3

\section{Introduction}

Migraine headaches within primary headaches are those localized on one side of the head, that arise in episodes, last 4-72 hours, increases with physical activities preventing one from completing tasks; with moderate or severe throbbing. Migraine headaches can be unilateral as well as bilateral. The localization of the pain is front temporal and per orbital. Migraine headaches can accompanied by nausea and/or vomiting, discomfort from light, sound/noise or smells. (Headache Classification Committee of the International Headache Society, The international classification of headache disorders zrd edition, 2013). 
According to the classification of The International Classification of Headache Disorders 3 (ICHD-3) migraines are divided into 6 main classes (Headache Classification Committee of the International Headache Society, The international classification of headache disorders 3rd edition, 2018). Migraine without Aura, Migraine with Aura, Chronic Migraine, Migraine Complications, Potential Migraine, Episodic syndromes associated with migraine. "Approximately $80 \%-85 \%$ of migraine headaches are Migraines without Aura while 15\%-20\% are Migraines with Aura. There can be various behavioural and mood changes during the stages of prodrome (prior to pain) or postdrome (after pain) of migraine attacks. Some of these changes can be yawning, lethargy, listlessness, stiffness of the neck, loss of concentration" (Öztürk, 2018).

Symptoms of Migraines with Auras are temporary focal neurological symptoms which are visual, sensory, motor, language and brainstem disorders. Aura appears before pain, develops slowly in minutes and lasts for 5-6o minutes. (ICHD $3^{\text {rd }}$ edition, BETA)

The Symptom Distress Check List - SCL-90-R used in the study has been developed by Leonard R. Derogatis et al, 1971, 1973, 1974, 1976, 1977) at the Psychedelic Research Unit of Johns Hopkins University utilizing the inventory of Hopkins Symptom Check List (HSCL). The Psychological Symptom Checklist SCL-9o-R: is a tool used to measure the psychological symptoms of the individuals and to determine what level the symptoms are and which areas they spread to (Kılıç, 1991).

4 new subscales, Anger - Hostility (HOS), Phobic Reaction (PHOB), Paranoid Ideation (PAR), psychoticism (PSY) have been added to the 5 HSCL Symptom subscale; Somatisation (SOM), Obsessive - Compulsive (O-C), Interpersonal Sensitivity (INT), Depression (DEP), Anxiety (ANK) and 4 answer categories ranging from «None» to «Advanced» marked with o-2-1-3-4 and with the addition of 5 response scales showing the degree of presence has been developed to form a comprehensible inventory consisting of 9 sub clauses, 9 subscales and one additional scale resulting in 10 symptom groups. 7 of the 90 items belong to the additional scale and fall outside these main groups. The items that constitute the tenth symptom group include eating and sleeping disorders and feelings of guilt (Dağ, 1991).

\section{Material and Method}

This study with participants from Cyprus American University and Girne American University consisted of 75 migraine subjects and 42 control subjects without headache in the 18-25 age group.

As a method, students who complained of headaches and wanted to voluntarily participate in the study were requested to complete a Headache questionnaire based on the ICHD-3 classification, which is internationally agreed upon as common ground for Migraine headaches.

The first questionnaire questions, asked if young subject with headaches had a systemic disease and the subjects who reported a systemic, neurological and secondary psychiatric disease were not included in the study.

Those who did not complete the questionnaire and those who gave inconsistent answers were excluded from the study.

Interviews were conducted with those that met the criteria and provided a family history.

The SCL-9o-R test was applied to 75 Migraine subjects who met the ICHC-3 criteria to reveal their psychological symptoms

The SCL-90-R test and a headache question was given to the 42 young university student control subjects without complaints of headaches.

In the SCL-9o-R Psychological Symptom Screening Test, the young students who participated in the study were asked of psychological symptoms that could be present in everyone using 90 different sentences. Attempts were made to rate the young students discomfort in the last month.

The rates were set from zero to 4 ( $0=$ not at all 1 : very little $2=$ moderately $3=$ severely $4=$ =xtremely)

Thus we tried to measure the scale of the psychological symptoms present in the students who graded themselves.

The responses were evaluated by a neurology specialist and clinical psychologist 
The result of the evaluation determined 75 Migraines (62 without Aura and 13 with Aura Migraines)

\section{Findings}

The study used the SPSS Statistical Method with the 75 Migraine (62 without Aura and 13 with Aura Migraines) and 42 control subjects without headache group The results obtained from the SCL-9o-R Psychological Symptom Search Test were evaluated by following tests

a) Descriptive Statistics for the Sample of Students,

b) Pearson Correlation Matrix,

c) ANOVA test.

\subsection{Results}

Table 1: Descriptive Statistics for the Sample of Students $(\mathrm{N}=75)$

\begin{tabular}{|c|c|c|c|c|c|c|}
\hline \multirow[b]{3}{*}{ Diagnosis } & \multicolumn{4}{|c|}{ Gender } & & \\
\hline & \multicolumn{2}{|c|}{ Male } & \multicolumn{2}{|c|}{ Female } & \multicolumn{2}{|c|}{ All } \\
\hline & Mean & SD & Mean & SD & Mean & SD \\
\hline controlSOM & .797 & 1.51 & 1.10 & 2.19 & .889 & 1.72 \\
\hline A M & 1.81 & 1.77 & 1.41 & .661 & 1.51 & 1.09 \\
\hline AUM & 1.33 & .353 & 1.89 & .738 & 1.80 & .712 \\
\hline controlANK & .524 & .434 & .423 & 297 & .492 & .396 \\
\hline A M & 1.46 & .498 & 1.36 & .598 & 1.39 & .571 \\
\hline AUM & .850 & .353 & 1.76 & .740 & 1.62 & .765 \\
\hline control O-C & .978 & .604 & 1.00 & .348 & .985 & .534 \\
\hline A M & 2.11 & .570 & 1.86 & .772 & 1.93 & .726 \\
\hline AUM & 1.89 & .565 & 2.35 & .661 & 2.28 & .647 \\
\hline control DEP & 1.57 & 2.23 & .739 & .528 & 1.32 & 1.91 \\
\hline A M & 1.87 & .690 & 1.71 & .663 & 1.76 & .669 \\
\hline AUM & 1.53 & .671 & 1.96 & .922 & 1.90 & .885 \\
\hline control INT & .672 & .689 & .623 & .419 & .657 & .613 \\
\hline A M & 2.06 & .721 & 1.56 & .773 & 1.69 & .779 \\
\hline AUM & 1.50 & .078 & 1.99 & 1.08 & 1.91 & 1.00 \\
\hline control PSY & .310 & .341 & .200 & .258 & .276 & .319 \\
\hline A M & 1.34 & .592 & .889 & .542 & 1.01 & .589 \\
\hline AUM & 1.10 & .989 & 1.20 & .789 & 1.18 & .777 \\
\hline control PAR & $.75^{2}$ & .688 & .858 & .480 & .785 & .627 \\
\hline A M & 1.66 & .864 & $1.5^{2}$ & 693 & 1.57 & .740 \\
\hline AUM & 1.16 & .707 & 1.74 & .949 & 1.65 & .916 \\
\hline control HOS & .902 & .610 & .743 & .614 & .853 & .608 \\
\hline A M & 1.66 & .987 & 1.39 & 1.01 & 1.47 & 1.00 \\
\hline AUM & .833 & .707 & 2.02 & .934 & 1.83 & .983 \\
\hline controlPHOB & .181 & .292 & .241 & .205 & .200 & .267 \\
\hline A M & .831 & .576 & .745 & .555 & .769 & $.55^{8}$ \\
\hline AUM & .928 & .706 & 1.22 & 1.00 & 1.18 & .942 \\
\hline control AS & .753 & .539 & .724 & .366 & .744 & .488 \\
\hline A M & 1.77 & .825 & 1.52 & .650 & 1.59 & .704 \\
\hline AUM & 1.99 & .403 & 1.85 & .694 & 1.87 & .646 \\
\hline control GSI & .635 & .434 & .593 & .275 & .622 & .389 \\
\hline A M & 1.62 & .506 & 1.43 & .531 & 1.48 & .527 \\
\hline AUM & 1.33 & .557 & 1.87 & .773 & 1.79 & .751 \\
\hline
\end{tabular}

$(\mathrm{N}=)$ for somatisation $=\mathrm{SOM}$, anxiety $=\mathrm{ANK}$, obsession=O-C, depression=DEP, interpersonal sensitivity $=I N T$, psychotic $=$ PSY, paranoia $=$ PAR, anger $=$ HOS, phobic $=$ PHOB, additional scaLe=AS, G.S.İndex=GSI Migraine without Aura $=$ AM, Migraine with Aura $=$ AUM The control group consisted of students who did not define headaches. 
Table 2: Pearson Correlation Matrix among the variables

\begin{tabular}{|c|c|c|c|c|c|c|c|c|c|c|c|}
\hline & SOM & $A N K$ & $\mathrm{O}-\mathrm{C}$ & $D E P$ & $I N T$ & $P S Y$ & PAR & HOS & PHOB & $A S$ & GSI \\
\hline Age & .001 & -.057 & .020 & .011 & -.004 & .029 & -.007 & -.099 & -.003 & .036 & -.027 \\
\hline SOM & & $.329^{*}$ & $.257^{* *}$ & $.354^{* *}$ & $.276^{* *}$ & $.25^{* *}$ & .129 & $.255^{* *}$ & $.333^{* *}$ & $.256^{* *}$ & $.357^{* *}$ \\
\hline ANK & & & $.666^{* *}$ & $.435^{* *}$ & $.705^{* *}$ & $.768^{* *}$ & $.55^{* *}$ & $.628^{* *}$ & $.759^{* *}$ & $.650^{* *}$ & $.887^{* *}$ \\
\hline $\mathrm{O}-\mathrm{C}$ & & & & $.353^{* *}$ & $.718^{* *}$ & $.620^{* *}$ & $.585^{* *}$ & $.508^{* *}$ & $.614^{* *}$ & $.617^{* *}$ & $.826^{* *}$ \\
\hline DEP & & & & & $.396^{* *}$ & $.416^{* *}$ & $.309^{* *}$ & $.345^{* *}$ & $.435^{* *}$ & $.323^{* *}$ & $.478^{* *}$ \\
\hline INT & & & & & & $.762^{* *}$ & $.714^{* *}$ & $.549^{* *}$ & $.723^{* *}$ & $.604^{* *}$ & $.867^{* *}$ \\
\hline PSY & & & & & & & $.628^{* *}$ & $.547^{* *}$ & $.726^{* *}$ & $.597^{* *}$ & $842^{* *}$ \\
\hline PAR & & & & & & & & $.561^{* *}$ & $.570^{* *}$ & $.469^{* *}$ & $.721^{* *}$ \\
\hline HOS & & & & & & & & & $.542^{* *}$ & $.465^{* *}$ & $.702^{* *}$ \\
\hline РНOB & & & & & & & & & & $.592^{* *}$ & $.821^{* *}$ \\
\hline AS & & & & & & & & & & & $.766^{* *}$ \\
\hline GSI & & & & & & & & & & & \\
\hline
\end{tabular}

${ }^{* *} \mathrm{p}<\mathrm{o}$. Somatisation =SOM, anxiety =ANK, obsession=O-C, depression=DEP, interpersonal sensitivity $=\mathrm{INT}$, psychotic $=$ PSY, paranoia $=\mathrm{PAR}$, anger $=\mathrm{HOS}$, phobic=PHOB, additional scale $=\mathrm{AS}$, General Symptom Index=GSI

Table 3: Summary of ANOVA testing the difference in these symptoms

\begin{tabular}{|c|c|c|c|c|c|c|c|}
\hline & & Sum of Squares & $\overline{\mathrm{Df}}$ & Mean Square & $\mathrm{F}$ & Sig. & MEANING \\
\hline \multirow[t]{3}{*}{ Somatisation } & Between Groups & 16,419 & 5 & 3,284 & 2,610 &, 026 & S \\
\hline & Within Groups & 234,054 & 186 & 1,258 & & & \\
\hline & Total & 250,473 & 191 & & & & \\
\hline \multirow[t]{3}{*}{ Anxiety } & Between Groups & 25,652 & 5 & 5,130 & 11,742 & ,ooo & $\mathrm{S}$ \\
\hline & Within Groups & 81,267 & 186 & ,437 & & & \\
\hline & Total & 106,919 & 191 & & & & \\
\hline \multirow[t]{3}{*}{ Obsession } & Between Groups & 31,810 & 5 & 6,362 & 16,226 & ,ooo & $\mathrm{S}$ \\
\hline & Within Groups & 72,928 & 186 & ,392 & & & \\
\hline & Total & 104,738 & 191 & & & & \\
\hline \multirow[t]{3}{*}{ Depression } & Between Groups & 7,147 & 5 & 1,429 & 1,191 &, 315 & NS \\
\hline & Within Groups & 223,184 & 186 & 1,200 & & & \\
\hline & Total & 230,332 & 191 & & & & \\
\hline \multirow[t]{3}{*}{ Interpersonal Sensitivity } & Between Groups & 34,303 & 5 & 6,861 & 14,153 & ,ooo & S \\
\hline & Within Groups & 90,165 & 186 &, 485 & & & \\
\hline & Total & 124,469 & 191 & & & & \\
\hline \multirow[t]{3}{*}{ psychotic } & Between Groups & 17,430 & 5 & 3,486 & 11,070 & ,ooo & S \\
\hline & Within Groups & 58,570 & 186 & ,315 & & & \\
\hline & Total & 76,000 & 191 & & & & \\
\hline \multirow[t]{3}{*}{ Paranoia } & Between Groups & 22,591 & 5 & 4,518 & 8,863 & ,ooo & S \\
\hline & Within Groups & 94,820 & 186 &, 510 & & & \\
\hline & Total & 117,411 & 191 & & & & \\
\hline \multirow[t]{3}{*}{ Anger } & Between Groups & 17,234 & 5 & 3,447 & 3,917 & ,002 & S \\
\hline & Within Groups & 163,655 & 186 &, 880 & & & \\
\hline & Total & 180,889 & 191 & & & & \\
\hline \multirow[t]{3}{*}{ Phobic } & Between Groups & 16,894 & 5 & 3,379 & 10,280 & ,ooo & S \\
\hline & Within Groups & 61,132 & 186 &, 329 & & & \\
\hline & Total & 78,026 & 191 & & & & \\
\hline \multirow[t]{3}{*}{ Additional Scale } & Between Groups & 22,897 & 5 & 4,579 & 10,676 & ,ooo & S \\
\hline & Within Groups & 79,783 & 186 &, 429 & & & \\
\hline & Total & 102,680 & 191 & & & & \\
\hline \multirow[t]{3}{*}{ G.S.I } & Between Groups & 25,037 & 5 & 5,007 & 18,744 & ,ooo & $\mathrm{S}$ \\
\hline & Within Groups & 49,691 & 186 &, 267 & & & \\
\hline & Total & 74,729 & 191 & & & & \\
\hline
\end{tabular}




\section{$3.2 \quad$ Findings}

1. Of the 75 migraine patients 55 are female (with average age of: 20.87), and 20 are male (with average age of: 22.15). The average age of the Migraine subjects is 21.21.

(The average age of 13 Migraines with Aura is 20.61. The average age of 62 Migraine without Aura is: 21.33).

The average age of the controlled group of 42 subjects without complaints of headaches is18.88 (the average age of the female subjects of the controlled group is 21.78 , and the average age of the male subjects of the controlled group is 21.35).

The average age of both sexes, jointly and severally in the Control group is higher than the migraine group and the migraine group with and without Aura

2. The Descriptive Statistics for the Sample of Students test, where the average values of both sexes were taken found that the average values of the migraine groups with and without aura individually is higher than the control group.

3. This was checked with Anova test. For the diagnostic group in Anova test with the exception of depression there are significant differences (Somatisation $\mathrm{p}<.05$, others $\mathrm{p}<.01$ ) however, there is no significant difference in depression $(\mathrm{p}=0.315)$.

4. No relationship was found between age and all psychological symptoms in the Pearson Correlation Analysis. There is a significantly positive connection between Somatisation (except paranoia) and all psychological symptoms $(\mathrm{p}<.05)$. There is a significantly positive connection between depression and all psychological symptoms. $(\mathrm{p}<.05)$ There is a significantly positive connection between anxiety, obsession, interpersonal sensitivity, psychoticism, paranoia, rage, phobia, additional scale, and all psychological symptoms.

\section{Argument}

Headache is associated with many psychiatric disorders, especially with anxiety and depression (Sayılgan, Domaç, Güleç, 2019).

Migarine headaches are commonly observed together with psychiatric disorders such as bipolar disorder (BD), phobia, depression, suicide tendency and attempt and anxiety disorder (Wang, Chen, Fuh, 2010).

In our study, symptom levels of somatization, anxiety, obsession, depression, interpersonal sensitivity, psychosis, paranoid, anger, phobic and additional scales investigated within Migraine groups with and without aura revealed higher average values than control group. This indicated psychiatric symptom similarities between young migraine subjects in our study and other studies on different age groups.

There was $35 \%$ psychiatric illnesses present in the study by Saylgan and colleauges carried out on migraine patients. These were $18.3 \%$ depression $5 \%$ anxiety disorder + depression and anxiety, $5 \%$ obsessive compulsive disorder, $3.3 \%$ dissociative disorder, $1.7 \%$ affective bipolar disorder and \%1.7 hypochondria.

Akhan et al found that with the SCL-90-9 test, somatisation, depression, anxiety and phobic anxiety subscale scores of migraine patients were significantly higher than healthy control group.(p<o.o1) The subscale scores of anger, hostility and psychotism were significantly higher than the healthy controlled group.(p<0.05) (Akhan, Alptekin, Bayburtoğlu, 1995).

In our test the average values of somatization, anxiety, depression, rage, phobia and psychoticism in both migraine groups were higher than the control group with no headache. This shows similarities with Akhan et al's studies. In our study, significant differences in average values except in depression were found between the migraine groups. (Somatization $\mathrm{p}<.05$, others $\mathrm{p}<.01$ ) Even though the level of depression in the migraine group is higher compared to the control group this is statistically insignificant. $(\mathrm{p}=0.315)$ This may be due to the migraine group consisting of only young university students between the age of 18-25 or the study not including different age groups. 
The study conducted by Merikandes et al found high rates of anxiety disorder and social phobia in migraine patients (Akhan et al, 1995). (Marikangas, Angst, Isler, 1990) High values of anxiety and phobia in both migraine groups and the control group with no headache was also found in our study.

Özden et al investigated obsessive - compulsive symptoms in Migraine patients and found that in terms of phobias these patients carried a higher risk of anxiety disorders and partial panic disorders. (Özden, Baykan, Ertekin, 2015). In our study the values of psychological symptoms of anxiety, obsession and phobia are higher in both migraine groups in comparison to the control group with no headache. The studies conducted by Kocabaş and Çelebi with boarding students from a vocation school for girls aged between 14-18 (Kocabaş,Çelebi, 1997) showed that in comparison to the control group the levels of anxiety, depression and neurotic tendency were higher in migraine and regressional headache groups. In our study, anxiety and depression levels were also higher than the control group without headache

Some authors (Merskey, 1975) mention that migraine attacks $(72 \%)$ can be precipitated by emotional factors (Kocabaş and Çelebi, 1997). Seby and Lance determined that migraine attacks became increasingly frequent by emotional factors (Kocabaş and Çelebi, 1997). (Selby, Lance, 1960). Many authors have reported that acute anxiety causes headaches in migraine and regressional headaches. (Kocabaş, Çelebi, 1997) (Merskey, Sandrini, Manzoni, Zanferrari, Nappi, 1993). (Sandrini, Manzoni, Zanferrari, Nappi, 1993) Major depressive disorder, bipolar disorder (Jette, Patten, Williams, Becker, Wiebe, 2008). (Hamelsky, Lipton, 2016), panic disorder and social phobia are common in cases of migraine headache. (Yaşar, Balıbay, Alay, Tekeli, Türker, Bayar, 2016). In the study conducted by Yaşar et al, levels of depressive symptoms were higher in the migraine group compared to the control group. This is also the case in our study. It has been reported that depression and anxiety are frequently associated with migraine with aura. (Yaşar et al, 2013) (Breslau, Schultz, Stewart, Lipton, Lucia, Welch, 2000). (Samaan, Farmer, Craddock, Jones, Korszun, Owen, McGulf, 2009). Our study also shows the same association.

In the study conducted by Yaşar et al no difference was found between the symptoms of anxiety, depression and obsessive-compulsive disorder in both migraine with and without aura. This is also the case in our study. (Both Yaşar et al and our study consisted of few cases of migraine with aura and young subjects). Somatic complaints are commonly observed in migraine headache patients and this is closely related to the patient's level of depression and anxiety. (Maizels, Burchette, 2004) (Öz, Erdem, Yücel, Akgün, Yozgatlı, Balıkçı, Durukan, Demirkaya, Odabaşı, 2011). The important factor that triggers migraine attacks is stress (Özden et al) (Wacogne, Lacoste, Guillibert, Hugues, Le Jeunne, 2003).

It is conspicuous that our study found that somatisation, anxiety and depression symptom levels were higher in migraine patients compared to control group without headache and shows similarities with the findings of Maizels - Burchette, 2004 and Özden et al.

Çelik, Arkar and İdiman found that depression and anger scores were significantly higher in migraine headache patients than in healthy subjects. (Çelik, Arkar, İdiman, 2010) Our study also showed that the average values of depression and anger symptoms in migraine patients were higher than the control group without headache.

Korkmaz and colleagues used the SCL-90-R Psychological Symptom Test on migraine patients aged between 18-49 and compared the patient and control group. In their study (Korkmaz, Kozgan, Korucu, Gönen, Yilmaz, Atmaca, 2019) they found high values somatization, anxiety ( $\mathrm{p}=0.000)$, depression $(\mathrm{p}=0.003)$, anger $(\mathrm{p}=0.02)$, interpersonal sensitivity $(\mathrm{p}=\mathrm{0.006})$, phobia $(\mathrm{p}=\mathrm{o.001})$, paranoid thoughts $(\mathrm{p}=\mathrm{0.012})$, psychosis $(\mathrm{p}=\mathrm{0.031})$, additional scale $(\mathrm{p}=0.014)$ and General Symptom Index $(\mathrm{p}=0.001)$.

In our study, except for depression, there are significant differences compared to the diagnosis group. (Somatisation $\mathrm{p}<.05$, anxiety $\mathrm{p}<.01$, obsession $\mathrm{p}<.01$, inter personal sensitivity $\mathrm{p}<.01$, psychosis $\mathrm{p}<$.o1, paranoid thoughts $\mathrm{p}<.01$, anger $\mathrm{p}<$.o1, phobia $\mathrm{p}<$.o1, additional scale $\mathrm{p}<.01$, GSI $\mathrm{p}<.01$ ) ). Both studies have similar findings 


\section{Conclusion}

The aim of our study was to detect migraine patients among young university students (18-25) and to investigate the psychological symptoms of these migraine patients. Our study revealed the presence of psychological symptoms in young migraineurs.

The comparison made in our study between the psychological symptoms of migraine groups and the control group found that the average value of both migraine groups are higher that the control group.

Similar findings were observed in our study and other studies when comparing the psychiatric symptoms of young university migraine patients (18-25) with the psychiatric symptoms of migraine patients in other studies involving different age groups.

\section{References}

Headache Classification Committee of the International Headache Society (IHS).(2013). The international classification of headache disorders 3 rd edition (beta version). Cephalalgia, International Headache Society,33,629-808.

Headache Classification Committee of the International Headache Society (IHS).(2018).The international classification of headache disorders 3rd edition. Cephalalgia, International Headache Society ,38,1-211.

Öztürk, M.,. (2018). Migren-atak ve profilaktik tedavi: Bașağrısı tanı ve tedavi.Türk Nöroloji Derneği Yayını. İstanbul: Galenos Yayınevi,51-66. https://www.noroloji.org.tr

Kılıç, M..(1991). Belirti tarama testi listesi:SCL-9o-R'nin geçerlilik ve güvenirliliği. Psikolojik Danışma ve Rehberlik Dergisi,1(2),45-52.

Dağ İ.,.(1991). Belirti tarama listesi SCL-9o-R'nin üniversite öğrencileri için güvenirliği ve geçerliği.Türk Psikiyatrı Dergisi,2(1),5-12.

Sayılgan N., Domaç F.M., Güleç H.(2019). Migren ve gerilim tipi başağrısı tanışı bireylerde psikiyatrik eştanı ve yaşam kalitesi ile ilișkisi: ön çalışma. Çukurova Medikal Jurnal, 44(1),44-51.

Wang Sj, Chen PK, Fuh JL. (2010).Comorbities of migraine: front neurol.1(16).

Akhan G., Alptekin K., Bayburtoğlu T.(1995). Migrenli hastalarda ruhsal belirti dağılımı. SDU Tip Fakültesi Dergisi,2(1),1-4.

Marikangas K.R., Angst J., Isler H (1990) Migraine and pschopathology: Arc gen psychiatry 47, 849-53.

Özden S.Y, Baykan B., Ertekin E., (2015) Migrenli hastalarda obsesif-compulsif belirtilerin araştırılması: Ağrı 27(1),18-25.

Kocabaș Z.,Çelebi A.(1997) Migren ve gerilim başağrısında anksiyete, depresyon ve nörotik eğilim düzeyleri:Düşünen Adam. 10(3),17-21.

Merskey H.,(1975). Psychiatric aspects of migraine: In Pearce J (ed). modem topics in migraine. London: William Heinemann Medical Book Limited, 52-63.

Selby G., Lance J.W.,(1960) Observations on 500 cases of migraine and allied vascular headache. J Neurol Neurosurg Psychiatry 23(23),32

Merskey H., Sandrini G., Manzoni G.C., Zanferrari C., Nappi G.(1993).An epidemiological approach to the nosography of chronic daily headache. Cephalalgia 13(12),72-77.

Sandrini G., Manzoni G.C., Zanferrari C., Nappi G.,(1993) An epidemiological approach to the nosography of chronic daily headache,Cephalalgia 13(12),72-77.

Jette N., Patten S., Williams J., Becker W., Wiebe S., (2008).Comorbidity of migraine and psychiatric disorders:a national population-based study: Headache, $(48), 501-16$.

Hamelsky S.W., Lipton R.B.,(20016). Psychiatric comorbidity of migraine: headache,(46), 1327-33.

Yaşar H., Balıbay H., Alay S., Tekeli H., Türker T., Bayar N.,(2016).Migren hastalarında anksiyete, depresyon ve obsesif-kompulsif belirti düzeyleri. Journal of Mood Disorders,3 (4), 156-161. www.jmood.org

Breslau N., Schultz L.R., Stewart W.F., Lipton R.B., Lucia V.C., Welch K.M.A.,(20oo). Headache and major depression:Is the association specific to migraine?. Neurology,54,308-313.

Samaan Z., Farmer A., Craddock N., Jones L., Korszun A., Owen M., McGulf P.(2009).Migraine in recurrent depression:casecontrol study.Br J Psychiatry,(194),350-4.

Maizels M., Burchette R.,(2004) Somatic symptoms in headache patients: The influence of headache diagnosis, frequency, and comorbidity.Headache (44),983-993. 
Öz O., Erdem M., Yücel M., Akgün H., Yozgatlı G., Balıkçı A., Durukan İ., Demirkaya Ş., Odabaşı Z.,(2011).Migren hastalarında öfke düzeyi ve öfke ifade tarzı.Gülhane Tıp Derg (53), 85-88.

Wacogne C., Lacoste J.P., Guillibert E., Hugues F.C., Le Jeunne C.,(2003). Stress, anxiety, depression and migraine. Cephalalgia, (23), 451-455.

Çelik D.B., Arkar H., İdiman F.,(2010) Migren başağarısı hastalarının öfke tarzları ile mizaç ve karakter özellikleri.Klinik Psikiatri,(13), 233-521.

Korkmaz S., Kozgan A., Korucu T., Gönen M., Yilmaz M.Z., Atmaca M.(2019) Psychiatric symptoms in migraine patients and their attitudes towards psychological support on stigmatization. J .Clin. Neurosci,(62),180-183. 